\title{
A CIDADE COM-FUSA \\ A Mão INOXIDÁvel do MERCADO E A \\ Produção da Estrutura Urbana nas Grandes METRÓPOLES LATINO-AMERICANAS
}

\author{
PEDRO ABRAMO
}

R E S U M O Com a crise do fordismo urbano regulamentar, o mercado imobiliário voltou a ter um papel determinante no processo de coordenação social do uso do solo e de produção da estruturação intra-urbana. A mão inoxidável do mercado de solo está de volta. $O$ trabalho apresenta uma leitura sobre a relação entre a produção da estrutura urbana e as formas de funcionamento dos mercados formais e informais de solo na América Latina. Propomos como hipótese que as cidades latino-americanas apresentam uma estrutura urbana particular quando comparada aos dois modelos tradicionais (cidade mediterrânea compacta e cidade anglo-difusa). O funcionamento do mercado de solo nas metrópoles latino-americanas produz simultaneamente uma estrutura urbana compacta e difusa. Essa estrutura urbana caracteristica das grandes urbes latino-americanas nominamos "cidade COM-FUSA".

P A L A V R A S - C H A V E Cidade informal; produção da estrutura urbana; mercado imobiliário informal e formal; mobilidade residencial.

\section{INTRODUÇÃO}

A crise do fordismo urbano no início dos anos oitenta nos países centrais, em particular na Europa, e o início da construção do que alguns comentaristas chamam da Nova Política Urbana pode ser considerada como o marco formal da institucionalização da cidade neoliberal (Moulaert, 2004). Outros processos acompanham esse movimento, em particular a crítica ao racionalismo construtivista do urbanismo moderno e a amplificação da audiência do discurso do multiculturalismo urbano e da fragmentação étnico-cultural e religiosa nas grandes cidades (Taylor, 2002). Porém, nesse trabalho, vamos realçar um fator que julgamos determinante na construção estrutural da cidade neoliberal e que chamaremos de "o retorno do mercado" como elemento determinante na produção da cidade. Ao longo do período fordista urbano, o mercado tinha um papel muito importante na produção das materialidades urbanas, porém, esse papel era mediado pelo Estado na definição das regras de uso do solo e nas características das materialidades urbanas (urbanismo moderno e decisóes de gasto estatal em infra-estrutura e equipamentos urbanos).

A crise do fordismo urbano se manifesta, sobretudo, através da crise do urbanismo modernista e regulatório com a flexibilização urbana e com a crise de financiamento estatal da materialidade urbana (habitação, equipamentos e infra-estrutura) e alguns serviços urbanos coletivos. Nos dois casos, o mercado ressurge como principal mecanismo de coordenação de produção das materialidades urbanas, seja pela via das privatizações de empresas públicas urbanas, seja pela hegemonia do capital privado na produção das materialidades residenciais e comerciais da cidade. Assim, a cidade neoliberal tem como me- 
canismo de coordenação das decisóes de uso do solo a predominância do mercado, ou, como preferimos dizer, do retorno da "mão inoxidável do mercado".

Nos países latino-americanos, a produção das cidades modernas resulta do funcionamento das duas lógicas modernas (mercado e Estado), mas também de uma terceira lógica, a lógica da necessidade. Foi a lógica da necessidade que moveu, e continua a mover, um conjunto de ações individuais e coletivas que promoveram a produção das "cidades populares" com o seu habitual ciclo ocupação/autoconstrução/auto-urbanização e, por fim, o processo de consolidação dos assentamentos populares informais (APIs). Recentemente, surge uma nova variante da produção da cidade popular que articula a lógica do mercado com a lógica da necessidade, e se manifesta socialmente como o "mercado informal de solo" (Abramo, 2003).

A hipótese do trabalho que propomos reafirma que o mercado, ao ser o principal mecanismo de hegemonia da coordenação das decisóes de uso do solo, produz uma estrutura ou forma de cidade particular e característica da América Latina. Uma estrutura "híbrida" de cidade do ponto de vista da sua morfologia de usos do solo vis-à-vis os dois modelos tradicionais da cidade moderna. A cidade moderna ocidental tem dois modelos paradigmáticos de conformação estrutural em termos materiais do seu ambiente construído. O primeiro desses dois modelos é identificado com o "modelo mediterrâneo" ou "continental", e a sua estrutura urbana se configura como uma "cidade compacta", onde o uso do solo é intensivo. O segundo modelo de cidade é o modelo anglo-saxão, e a sua manifestação espacial é a de uma "cidade difusa" com um uso do solo fortemente extensivo, de fraca intensidade e baixa densidade predial e residencial.

Nossa hipótese, que vamos desenvolver ao longo desse trabalho, é a seguinte: o funcionamento do mercado de solo nas grandes cidades latino-americanas promove de forma simultânea uma estrutura de cidade compacta e difusa. Assim, as cidades latino-americanas têm uma estrutura urbana do uso do solo e das suas materialidades que, ao se compactarem, também se difundem e, ao se difundirem, se compactam. Nesse sentido, a produção da estrutura urbana das grandes cidades latino-americanas, ao conciliar a forma compacta e a forma difusa do uso do solo, promove uma forma de cidade particular: a cidade COM-FUSA.

Vamos demonstrar que tanto o mercado formal, como o mercado informal de solo e de edificações produzem simultaneamente, e por razóes particulares vinculadas às suas próprias lógicas de funcionamento do mercado e de reprodução dos capitais, uma cidade COM-FUSA. Em uma palavra, o funcionamento do mercado imobiliário formal produz uma forma de cidade compacta e difusa, assim como o funcionamento do mercado informal de solo também produz uma forma de cidade popular ou informal compacta e difusa.

Ademais, vamos enfatizar que a produção e a reprodução da forma COM-FUSA das grandes cidades latino-americanas é alimentada por um duplo processo, ou círculo de retro-alimentação dos mecanismos de promoção da forma compacta e difusa do uso do solo urbano. Veremos que o mercado de solo se caracteriza por dois círculos de retro-alimentação da forma COM-FUSA; um de natureza formal e o outro com características informais. $\mathrm{O}$ resultado da produção das materialidades urbanas e, sobretudo, dos mecanismos promotores do uso do solo nos conduz a sublinhar uma lógica interna de funcionamento do mercado formal e do mercado informal que promovem um círculo perverso, em que a compactação alimenta a difusão e a difusão alimenta a compactação. Em outras palavras, o retorno da mão inoxidável do mercado de solo produz e potencializa 
uma estrutura espacial de uma cidade COM-FUSA. Como podemos imaginar, essa estrutura COM-FUSA, ao promover demandas de equipamentos e de serviços com sinais espaciais diversos, é um fator que dificulta a elaboração de políticas urbanas mais equitativas em termos socioespaciais.

\section{A PRODUÇÃo E REPRODUÇÃO DA CIDADE POPULAR INFORMAL: O MERCADO INFORMAL DE SOLO URBANO}

A cidade popular ou informal na América Latina não é um fenômeno recente, e podemos identificar processos de produção de territórios populares urbanos à margem das regras e das normas oficiais desde o tempo da colônia em praticamente todos os países de colonização portuguesa e espanhola. Porém, o processo de urbanização acelerado do século XX tem um papel determinante na amplificação desse processo de produção de cidades populares informais. Grosso modo, podemos dizer que na maior parte dos países latino-americanos a produção da cidade popular está vinculada diretamente à configuração de estruturas de provisão de moradias e de equipamentos e serviços urbanos truncados (Vetter e Massena, 1981) característicos de um regime de acumulação fordista excludente (Coriat e Sabóia, 1989) ou periférico (Lipietz, 1991). A urbanização fordista acelerada e excludente na América Latina promoveu um Estado do Bem-Estar urbano que atende sobretudo uma parcela restrita da população urbana. A estrutura social extremamente estratificada e com grandes diferenciais de acesso a riqueza (concentração de renda) gerou o surgimento de açóes urbanas coletivas ou individuais de ocupação de solo (organizadas e/ou espontâneas) movidas por uma lógica da necessidade de ter acesso a vida urbana (Abramo, 2005), ou, nos termos de Agambem, um movimento de reafirmação da vida em relação ao direito que não incorporava a vida no direito (Agamben, 2004, p.130).

A lógica da necessidade impulsiona o processo de ocupação popular de terras urbanas no início do século XX e, a partir da urbanização acelerada dos anos 50, vai se transformar na principal forma de acesso dos pobres ao solo urbano em muitos países latinoamericanos. Em alguns países onde o Estado do Bem-Estar fordista excludente promoveu a produção estatal de moradias, temos um padrão de provisão de solo urbano popular com dois vetores: a ocupação popular e a produção de moradias em conjuntos habitacionais ou lotes urbanizados (Duhau, 2001). Porém, a fragilidade dos sistemas de provisão pública na maior parte dos países latino-americanos e o crescimento da urbanização vai transformando paulatinamente a lógica da necessidade e a sua ação concreta, isto é, a ocupação popular, na forma dominante de acesso dos pobres a terra urbana.

A crise dos anos oitenta e dos sistemas nacionais de provisão habitacional em praticamente todos os países latino-americanos terá duas grandes conseqüências. A primeira foi um incremento do ciclo de ocupação e sobretudo o seu aparecimento em alguns países onde esse fenômeno não era muito presente (Uruguai, Paraguai). A segunda conseqüência da crise dos anos oitenta foi a consolidação e a potencialização de um mercado informal de terras urbanas.

Esse mercado informal popular existia em muitos países desde o início do século XX, fosse na forma do mercado de locação em cortiços ou outras formas precárias de moradia, fosse na mercantilização ilegal de terras peri-urbanas. A partir dos anos cinqüenta, encontramos alguns países latino-americanos onde a forma dominante de acesso a terra ur- 
bana é o mercado informal de solo. O caso mexicano é um exemplo concreto de predomínio do mercado informal a partir da privatização individualizada (venda de lotes individuais) das terras coletivas ejidais rurais (Azuela, 1989). Outro caso conhecido é o da cidade de Bogotá, onde praticamente toda a cidade popular tem na sua origem uma venda informal de solo urbano ("urbanização pirata"). Isto é, o acesso dos setores populares a um lote urbano é operado pelo mecanismo da mão do mercado informal de solo (Maldonado, 2005; Jaramillo, 2001).

A existência do mercado informal de solo é atribuída a vários fatores, mas sobretudo, a uma legislação urbanística modernista que dialoga com os estratos de renda elevados das cidades latino-americanas. O modelo de cidade formal modernista das elites latino-americanas impõe um conjunto de requisitos normativos que produziu uma verdadeira barreira institucional para a provisão de moradias para os setores populares com rendimento abaixo de três salários mínimos, e induziu a ação irregular e/ou clandestina de loteadores e processos de ocupação popular de glebas urbanas e peri-urbanas (Rolnik, 1999; Maricato, 2001). Essa manifestação de movimentos de ocupação e/ou de surgimento de mercados informais de solo urbano se repetiu em praticamente todos os países latino-americanos. Nesse sentido, podemos afirmar que esse duplo movimento se constitui em uma das principais características da formação socioespacial das grandes cidades latino-americanas.

No marco dessa característica estrutural da formação social e urbana latino-americana, vamos sublinhar o que identificamos como o retorno, ou a reafirmação, do mercado de solo como uma força que potencializa a produção de uma estrutura socioespacial desigual. Porém, esse mercado retorna assumindo duas formas institucionais diferentes. $\mathrm{O}$ mercado retorna com a sua face institucional formal, isto é, no marco de um Estado de Direito, mas também com uma característica institucional informal. Em uma palavra, o mercado informal popular de solo urbano vem crescendo em praticamente todos os países da América Latina e se transforma em um importante mecanismo de provisão de solo e de moradias para os setores populares.

A exceção dessa afirmação geral é o caso do Chile, onde, nos últimos anos, sua política neoliberal de provisão habitacional vem reduzindo de forma substantiva o déficit habitacional do país (Sabatini, 2003). Porém, o relativo sucesso do caso chileno vem se revelando paradoxal. A política chilena de moradias foi elaborada com o objetivo de produzir, via mercado, moradias populares, e assim formalizar o informal. Essa política se inicia durante a ditadura de Pinochet com o objetivo de acabar com os "acampamentos populares”, vistos então como um foco potencial de resistência à ditadura. Essa política sobreviveu ao regime militar e foi incorporada como uma das principais políticas públicas dos governos pós ditadura. Porém, nos últimos dez anos, alguns indicadores sobre as características dos conjuntos habitacionais chilenos revelam dois fenômenos não esperados: um crescimento importante dos preços da terra (urbana e peri-urbana) e o conseqüente deslocamento dos novos conjuntos para áreas muito distantes do núcleo urbano (Sabatini, 2005), e um rápido processo de informalização do formal (Rodrigues, 2004). $\mathrm{O}$ retorno da informalidade nas áreas formais dos conjuntos habitacionais tem duas dimensões de informalidade. A primeira, de natureza urbanística, e a segunda, o surgimento de um mercado informal nesses conjuntos habitacionais.

Assim, o crescimento do mercado informal de solo é uma realidade nas grandes cidades latino-americanas, e as expectativas de adoção de políticas neoliberais de titulação fomentadas pelas agências internacionais com a chancela intelectual de Sotto podem po- 
tencializar essa tendência (Smolka, 2003; Fernandes, 2003). Nossa questão no próximo item será a de apresentar alguns elementos para uma primeira aproximação do funcionamento do mercado informal de solo e as suas conseqüências em termos de uso do solo e de estrutura urbana nas áreas informais urbanas.

\section{EM DIREÇÃO AO ENQUADRAMENTO DO MERCADO INFORMAL DE SOLO: O QUE É O MERCADO INFORMAL? ELE REALMENTE EXISTE?}

Uma questão delicada e objeto de muitas discussões é a definição de informalidade (Azuela, 2001). Não vamos reproduzir aqui esse debate, mas vamos fazer uma opção clara sobre a noção que vamos utilizar para nos referir a informalidade urbana ou do uso do solo. A primeira observação é que informalidade não é um conceito, tal como exploração, marginalidade, espoliação e outros que serviram para uma descrição dos fenômenos urbanos latino-americanos. Nossa perspectiva nesse trabalho é a de tomar o termo informalidade como um termo descritivo, portanto, pré-analítico. A informalidade em seu sentido descritivo é polifônica e serve para descrever fenômenos em várias disciplinas (economia, sociologia, lingüística, antropologia, direito, etc.) e situaçóes concretas da vida social. Vamos nos restringir à dimensão urbana propriamente dita, ou seja, aquela que nos remete ao uso do solo urbano.

Nossa primeira aproximação ao termo informalidade é a partir da definição proposta por Bagnasco (1999) e que nos remete ao campo disciplinar dos direitos:

Se chamamos de economia formal o processo de produção e de trocas de bens e serviços regulados pelo mercado e promovidos e realizados por empresas industriais e comerciais com o objetivo do lucro e que atuam submetidas às regras do direito comercial, fiscal, do trabalho, etc., podemos chamar economia informal todo o processo de produção e de troca que não se submete a um desses aspectos ${ }^{1}$

Em seguida, Bagnasco conclui sua definição com as seguintes recomendações:

O aspecto mais complicado, e efetivamente o mais interessante dessa diferenciação está no fato de que os elementos formais e informais estão imbricados em estruturas de ação social (...) a conclusão importante que podemos sugerir seria que a economia informal, enquanto tal, não deveria estar no centro da pesquisa (acadêmica), mas sobretudo a relação do formal e do informal nas estruturas reais de ação" ${ }^{2}$

Assim, podemos tirar duas lições interessantes da citação acima de Bagnasco. A primeira diria respeito a uma definição minimalista de economia informal urbana, na qual ela seria um ato mercantil de comercialização e/ou locação do solo (edificado) que estaria fora do marco institucional do direito urbanístico, do direito econômico e comercial, do direito de propriedade e dos outros direitos civis que regulariam o uso e a propriedade do solo urbano. Ou seja, o mercado informal transaciona um bem (material ou imaterial) à margem do marco regulatório da esfera jurídico-política do Estado de Direito moderno.

Seguindo essa aproximação de Bagnasco, podemos dizer que a informalidade urbana seria um conjunto de irregularidades em relação aos direitos: irregularidade urbanísti-
1 No original: "se chiamiamo economia formale i processi de produzione e scambio di bieni e servizi regolati dal mercato e realizzati tipicamente da impresi industriali e comerciali orientate al profito, che agiscono sottomesse alla regole del diritto commerciale, fiscale, del lavoro, possiamo chiamare economia informale tutti quei processi di produzione e di scambio che tendono a sottrarsi per uno o piò aspetti a questi caratteri distintivi".

2 No original: "l'aspetto piò complicato, e del resto piò interessante, di questa differenziazione sta nel fatto che spesso elementi formali e informali sono stretamente intrecciati in determinate strutture d'azione (...) la conclusione importante è allora che non l'economia informale, inquanto tale, deve essere al centro di problemache scientifiche di ricerca, ma piuttosto il gioco del formale $\mathrm{e}$ dell'informale in concrete strutture d'azione". 
ca, irregularidade construtiva e irregularidade em relação ao direito de propriedade da terra (Alegria, 2005). No caso de um mercado informal de solo, a informalidade da economia do uso do solo nos remete a essas três irregularidades, mas também a outras irregularidades relativas aos contratos de mercado que regulam as transações mercantis. Assim, o mercado informal também seria (i) ou (a)regular em relação aos direitos econômicos. Assim, o mercado informal de uso do solo é a somatória de duas dimensōes da informalidade: a informalidade urbana e a informalidade econômica.

A maior parte dos economistas diria que o mercado é regulado por instituições fortes que garantem que a sua regularidade esteja nos marcos dos direitos legais, isto é, aqueles direitos que estariam contemplados e garantidos por um sistema jurídico associado ao Estado (Roemer, 2001). Para os economistas institucionalistas tradicionais (neo-institucionalistas), quando encontramos instituições informais nas relações de mercado, elas estariam subordinadas às instituiçôes legais e serviriam para aumentar a sua eficácia institucional, ou seja, minimizar os custos de transação (Williamson, 1985).

Partindo desse enquadramento, podemos buscar a superação da definição da economia institucionalista tradicional e acrescentar a possibilidade da existência de um conjunto de instituiçóes e de normas informais produzidas historicamente nos assentamentos populares pela via das práticas sociais que de fato configurem um sistema de regulação informal das transações mercantis informais. Assim, propomos uma segunda qualificação para a existência de um mercado informal. O mercado informal de solo deve estar fora dos marcos dos direitos, mas deve ter uma estrutura institucional própria que garanta a reprodução temporal das práticas mercantis informais de compra, venda e locação de solo e/ou imóveis. Em outras palavras, o mercado informal deve ter instituições informais que permitam o funcionamento do mercado e garantam em termos inter-temporais e inter-generacionais os contratos de natureza implícita estabelecidos nas transações informais de mercado.

No caso do mercado informal de solo, onde temos irregularidades (informalidade) de natureza da titulação, das normas urbanísticas e construtivas, os contratos de compra, venda e locação não poderiam ser considerados contratos com o amparo da lei, pois os seus objetos estariam irregulares em relação aos direitos regulatórios. Isso significa que qualquer conflito não pode ser resolvido pelos instrumentos de mediação e de execução legais. Assim, essas transações não seriam objeto da regulação e das sanções que servem de garantia aos agentes envolvidos em todas as relaçôes contratuais da economia formal.

Quando a lei não se constitui no elemento de garantia das relações contratuais de mercado, outras formas de garantia devem se desenvolver para restabelecer uma relação de confiança entre as partes envolvidas na relação contratual de mercado. Quando não há confiança que os contratos serão respeitados e não há mecanismos coercitivos de cumprimento contratual entre as partes, os contratos de mercados deixam de existir, ou seja, o mercado não se reproduz a partir de relaçóes mercantis e deixa de existir como mecanismo de coordenação das ações individuais (Bruni, 2006). No caso do mercado informal e popular de solo urbano, outras formas de garantias devem se construir socialmente para que as partes estabeleçam uma relação de confiança em respeito aos termos contratuais estabelecidos entre compradores e vendedores no mercado de comercialização, e entre locatários e locadores no mercado de locação. Do contrário, a relação de troca mercantil não se realiza em razão da desconfiança mútua de um eventual rompimento unilateral do contrato informal. Em outras palavras, sem as instituiçóes formais, o mercado informal de solo deve estabelecer as suas próprias instituiçóes reguladoras, in- 
cluindo os mecanismos coercitivos, no caso de rompimento contratual unilateral de uma das partes (Abramo, 2009). Essas instituições do mercado informal permitem que os contratos implícitos estabelecidos entre as partes sejam respeitados em termos inter-temporais e inter-generacionais.

No caso do mercado informal de solo urbano, uma base importante que garante o funcionamento do mercado e da sua cadeia contratual são as relaçôes de confiança e de lealdade que as duas partes contratantes estabelecem entre si; assim, os compradores e os vendedores, da mesma maneira que os locadores e locatários, depositam no outro uma relação de confiança que tem como base a expectativa de reciprocidade a partir de uma relação de lealdade entre as partes. A base dessa instituição informal de mercado não é de caráter legal, mas depende da permanência no tempo de uma forma particular de interdição social: a forma confiança-lealdade. Essa relação de reciprocidade interpessoal marca muitas relações sociais (Collins, 2004), mas, no caso de relações mercantis, ela foi excluída pela característica do mercado de promover um encontro contratual entre anônimos.

No caso do mercado informal e popular de solo em que a relação de reciprocidade confiança-lealdade é uma das instituições fundadoras da possibilidade de existência da troca mercantil informal, temos a necessidade de uma personalização das relações contratuais. Essa personalização pode não ser totalmente transparente e assumir um caráter opaco, mas a personalização (alguém que vendeu ou alugou e alguém que comprou ou alugou) introduz a possibilidade da relação de confiança-lealdade na constituição de uma relação contratual que por definição é implícita (informal), isto é, não está garantida pelos direitos que regulam os contratos econômicos. Assim, no mercado informal de solo são justamente a eliminação da impessoalidade e a personalização da relação contratual que garantem o mecanismo de confiança e lealdade que permite um contrato de compra e venda ou locação informal (Abramo, 2009).

Gráfico 1 - Características informacionais do mercado informal de solo no Brasil - Compradores e locatários, 2006

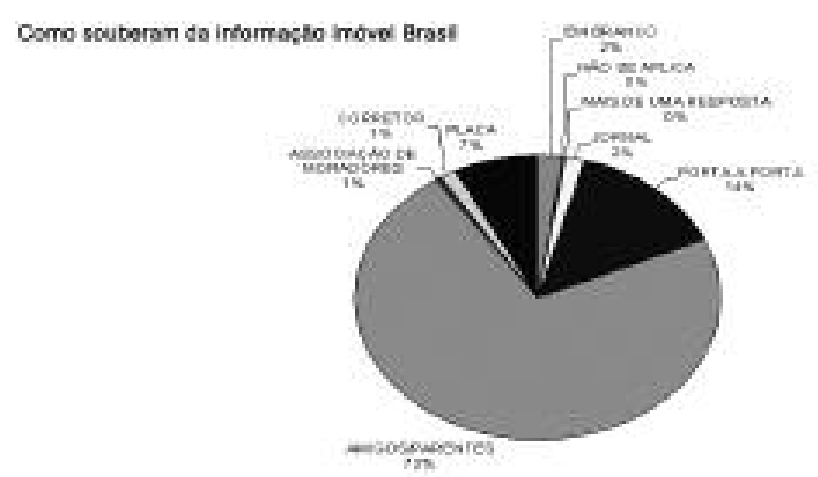

Fonte: Abramo, 2006/Infosolo-Brasil.

O gráfico acima sobre as características informacionais do mercado informal nos assentamentos consolidados é interessante, pois revela que praticamente todos os compradores e locadores tiveram acesso a informação dos imóveis ou dos lotes que compraram ou alugaram através de um parente ou amigo. Esse parente ou amigo que serviu de transmissor da informação de mercado também é um parente ou amigo dos vendedores e lo- 
cadores, e serve como uma "argamassa interpessoal" no estabelecimento da relação de confiança e de lealdade entre as duas partes da transação do mercado informal de solo. Assim, os contratos mercantis do mercado informal de solo estão ancorados em uma trama de relações de amizade e/ou parentesco que garantem a estabilidade temporal das relações de confiança e lealdade entre os agentes que assumem uma relação contratual (Abramo, 2009).

Porém, o mundo do mercado informal de solo não pode ser visto como um mundo idílico onde não há relações oportunistas e conflitivas entre as partes contratantes. Como dizem os poetas, a alma humana é um desconhecido que se revela a partir de sonhos, fantasmas, paixões e ódios. Assim, os contratos mercantis são uma forma social de intermediação de relações pessoais que se estabelecem a partir da mudança de posse ou de propriedade de bens ou serviços (tangíveis ou intangíveis) que envolvem homens e mulheres com alma humana, portanto, suscetíveis a mudar de atitude ou comportamento em função das suas emoções, prazeres, interesses e loucuras. Nesse sentido, uma trama de relações de amizade e/ou parentesco, por mais entremeada que seja, não garante de forma duradoura e perfeita as relaçóes de confiança e lealdade nos contratos mercantis do mercado informal de solo. A possibilidade de uma ruptura unilateral do contrato implícito e da relação de confiança e lealdade existe e será uma ameaça para o funcionamento do mercado informal. Aqui surge a necessidade de alguma mediação institucional que assuma a posição de um terceiro, ou seja, que esteja acima das partes envolvidas, e que sua ação promova o retorno aos termos do contrato informal inicial ou eventualmente abra um espaço de negociação entre as partes para redefinir os seus termos pactuados anteriormente.

Essa figura, que vamos chamar de "autoridade" de mediação contratual é determinante para a manutenção dos contratos informais, e a sua permanência no tempo garante a condição inter-temporal e inter-generacional dos contratos do mercado informal de solo. A hipótese que levantamos a partir de pesquisas de campo sobre os mecanismos contratuais do mercado informal de solo (Abramo, 2005) é a de que nos assentamentos populares informais se constitui uma "autoridade local" que serve de figura mediadora dos conflitos nessas comunidades populares. Essas autoridades locais são o resultado de processos históricos locais que atribuem um lugar de autoridade local constituída a partir de uma infinidade de processos sociais legitimadores. Nesse sentido, a constituição da legitimidade comunitária da autoridade local se revela a partir da trajetória histórica de cada comunidade. Essa legitimidade pode ser de natureza religiosa, étnica, cultural, política ou mesmo a partir da violência e do controle pela força, como constatamos em algumas pesquisas empíricas sobre o mercado informal na América Latina (Abramo, 2009). Como a literatura de antropologia econômica nos revela em muitos estudos, os mecanismos de convivência comunitária que garantem a ordem social local exigem algum tipo de forma coercitiva para restringir e controlar os comportamentos conflitivos (ou desviantes). Essas formas podem assumir a forma de uma força coercitiva coletiva passiva, representativa e/ou impositiva (Duty e Weber, 2007).

No caso do mercado informal de solo, as autoridades locais servem de instituição mediadora dos conflitos contratuais e permitem que esses contratos sejam respeitados e/ou negociados entre as partes, garantindo, dessa forma, a sua manutenção inter-temporal e inter-generacional. Muitos estudos antropológicos sobre a forma operacional dos mercados e de organizaçóes formais descrevem formas de coerção que não se restringem a sua dimensão coercitiva legal (Duty e Weber, 2007). Da mesma maneira, no mercado 
informal de solo identificamos formas e mecanismos coercitivos muito distintos, mas que servem para garantir o que podemos chamar de "pacto contratual" de mercado.

A história social e política de cada assentamento constrói e desconstrói esses mecanismos coercitivos. Mas, o fato importante é que haja efetivamente uma "autoridade local" que sirva de mediadora nos casos de ruptura e de conflitos no cumprimento dos contratos mercantis do mercado informal, e ainda, que disponha de mecanismos coercitivos (punição) no caso de uma mediação pacífica malsucedida (Abramo, 2009). Como sabemos, não há mercado sem instituições que estabeleçam a mediação interpessoal nas relações mercantis. Nesse sentido, o mercado informal de solo nos assentamentos consolidados depende da existência de relações de confiança e lealdade entre as duas partes do contrato informal, em geral sustentadas pela trama de relações de amizade e/ou parentesco que permite uma personalização opaca ou transparente da relação mercantil e o estabelecimento de contratos implícitos e da figura de uma "autoridade local" que serve de fiador desses contratos em termos inter-temporais e inter-generacionais. Essas duas características definem o núcleo básico das instituiçōes informais do mercado informal de solo.

Antes de passar a uma tentativa de estabelecer uma taxonomia dos sub-mercados informais de solo, gostaria de recuperar a segunda sugestão de Bagnasco e que enfatiza a importância de não transformar a economia informal em um objeto em si mesmo de análise. Bagnasco afirma, e seguimos a sua sugestão, que a melhor forma de entender a economia informal é a partir da sua relação de interação com a economia formal. Em trabalho anterior sublinhamos que as formas de interação entre os mercados formais e informais de solo podem ser de natureza complementar, de concorrência ou de efeitos de borda com mútua influência no comportamento e estratégias dos agentes dos dois mercados (Abramo, 2005).

No caso desse trabalho, vamos sublinhar a interação entre o mercado formal e informal de solo a partir das suas resultantes agregadas em termos de uso do solo urbano, ou seja, na produção e na reprodução da forma urbana das grandes cidades latino-americanas. Como adiantamos na introdução, pretendemos demonstrar que há uma similitude de resultados espaciais no uso resultante do funcionamento dos sub-mercados formais e informais. Como veremos a seguir, o funcionamento desses dois sub-mercados produz simultaneamente uma estrutura compacta e difusa do uso do solo. Além disso, encontramos nos dois sub-mercados forças de retroalimentação da dinâmica de produção da estrutura urbana COM-FUSA.

\section{OS DOIS SUB-MERCADOS DE SOLO INFORMAL URBANO}

O mercado de terras informal pode ser classificado em dois grandes sub-mercados fundiário-imobiliário. Tradicionalmente, a literatura de economia do uso do solo utiliza o critério de "substitutibilidade" dos bens fundiários e/ou imobiliários para definir os submercados de solos urbanos. Utilizando um conjunto de critérios que vamos apresentar em seguida, podemos, em termos esquemáticos, classificar o mercado popular informal de solo urbano da seguinte maneira:

1. Sub-mercado de loteamentos (urbanizações piratas);

- clandestinos

- irregulares 
2. Sub-mercado nos assentamentos populares informais (APIs) consolidados

$$
\begin{array}{cl}
2.1 \text { Residencial } & \text { - comercialização } \\
& \text { - aluguel } \\
\text { 2.2 Comercial } & \text { - comercialização } \\
& \text { - aluguel }
\end{array}
$$

No nosso caso, incorporamos a definição de "insubstitubilidade" como uma das variáveis chave para uma construção axiomática dos estudos sobre a estrutura do mercado, e analisamos outros elementos que consideramos importantes para definir uma primeira clivagem do mercado informal. Assim, definimos como elementos determinantes da estrutura do mercado os seguintes elementos: características da oferta e da demanda de solo; poder de mercado dos agentes econômicos (oferta e demanda); características informacionais do mercado (assimetrias e transparências de informação); características dos produtos (homogêneos ou heterogêneos); externalidades (exógenas e endógenas); racionalidades dos agentes (paramétrica, estratégica, etc.) e ambiente da tomada de decisão (risco probabilístico ou incerteza radical). A identificação dessas variáveis aproxima conceitualmente a nossa abordagem do mercado imobiliário informal do tratamento moderno da teoria econômica de mercado, permitindo, portanto, identificar conceitualmente as particularidades e as semelhanças do mercado informal de solo com os outros mercados formais da economia. A partir dessas variáveis, procuramos identificar diferenças substantivas nos mercados de terra informais a fim de estabelecer uma primeira aproximação da definição de sub-mercados informais. O resultado desse exercício pode ser visto no quadro abaixo e permite definir dois grandes sub-mercados de solo informais que denominamos: 1) sub-mercado de loteamentos e 2) sub-mercado de áreas consolidadas (Abramo, 2009, 2005 e 2003b).

\begin{tabular}{|c|c|c|}
\hline & Loteamentos & Assentamentos consolidados \\
\hline Estrutura de mercado & oligopólica & $\begin{array}{l}\text { competência com mercado } \\
\text { "racionado" }\end{array}$ \\
\hline $\begin{array}{l}\text { Agente dominante e } \\
\text { determinação de preços }\end{array}$ & $\begin{array}{l}\text { fracionador com capacidade } \\
\text { de "mark up" urbano }\end{array}$ & $\begin{array}{l}\text { comprador ("entrante") e } \\
\text { vendedor ("saínte") } \\
\text { tensão entre oferta e demanda }\end{array}$ \\
\hline $\begin{array}{l}\text { Assimetria de poder de } \\
\text { mercado }\end{array}$ & forte & variável \\
\hline Característica do produto & $\begin{array}{l}\text { homogeneidade relativa (lote) } \\
\text { com variaçóes de localização } \\
\text { e metragem }\end{array}$ & heterogeneidade \\
\hline Externalidades & $\begin{array}{l}\text { exógenas (hierarquia de } \\
\text { acessibilidade + características } \\
\text { físicas e topográficas) }\end{array}$ & endógenas + exógenas \\
\hline $\begin{array}{l}\text { Racionalidade e } \\
\text { antecipação }\end{array}$ & $\begin{array}{l}\text { estratégica com informação } \\
\text { incompleta (jogo da anteci- } \\
\text { pação de infra-estrutura) }\end{array}$ & $\begin{array}{l}\text { pluralidade de racionalidades } \\
\text { e objetivos de antecipação }\end{array}$ \\
\hline Informação & incompleta e imperfeita (risco) & $\begin{array}{l}\text { assimetria informacional e im- } \\
\text { previsibilidade (incerteza radical) }\end{array}$ \\
\hline
\end{tabular}

Quadro 1 - Marco comparativo das características do mercado informal de loteamentos e do mercado informal em assentamentos populares consolidados: taxonomia dos submercados 
O primeiro desses sub-mercados (loteamentos) é, em grande medida, definido por uma estrutura oligópolica de mercado, enquanto o segundo sub-mercado (áreas consolidadas) apresenta um estrutura concorrencial, porém, com uma oferta racionada; isto é, a oferta no sub-mercado de áreas populares informais (APIs) consolidadas é inelástica em relação ao aumento da oferta. Como veremos adiante na descrição do circuito perverso de retroalimentação dos dois sub-mercados, essa característica de inelasticidade terá um papel importante no crescimento dos preços informais em áreas consolidadas, induzindo algumas famílias a se deslocarem para a periferia pela porta de acesso do mercado informal de loteamentos. Em outras palavras, a inelasticidade da oferta no sub-mercado em áreas consolidadas gera uma demanda potencial para o sub-mercado de loteamentos informais.

Os dois sub-mercados de solo informal podem ser identificados na estrutura urbana da cidade em áreas bem precisas e com distintas funcionalidades no processo de vertebração urbana. O primeiro sub-mercado opera o fracionamento de glebas na periferia das cidades, constituindo-se no principal vetor de expansão da malha urbana e da dinâmica de periferização precária cuja característica principal nas grandes cidades latino-americanas é a inexistência (ou precariedade) de infra-estruturas, serviços e acessibilidade urbana. A lógica de funcionamento desse mercado de loteamentos é oligopólica na formação dos seus preços, mas as práticas de definição dos produtos e do seu financiamento nos remetem a tradiçõos mercantis pré-modernas, em que a "personifição opaca" adquire um papel importante de ajuste da oferta às preferências e à capacidade de gasto da demanda.

A estrutura oligopólica na formação dos preços é um dos fatores da alta rentabilidade mercantil dessa atividade, mas a flexibilidade no ajuste dos produtos e na adequação familiar às formas de financiamentos informal é um fator de atratividade para os setores populares. Essas duas características articulam o aspecto de modernidade oligopólica e de flexibilidade pós-moderna em relaçåo à oferta de lotes informais com uma dimensão tradicional de personalização da relação mercantil, definindo um nexo moderno-tradicional de natureza nova no mercado informal que assegura a sua atratividade tanto para os "urbanizadores piratas" quanto para a demanda popular. Os produtos desse sub-mercado de loteamentos são relativamente homogêneos, e os seus principais fatores de diferenciação nos remetem a dimensões físicas, topográficas e às externalidades exógenas relativas à posição do loteamento na hierarquia de acessibilidades e de infra-estrutura urbana. Nesse sentido, a produção informal de lotes pode adquirir uma certa economia de escala, ainda que a temporalidade da venda destes lotes seja muito instável e dependa de fatores externos às variáveis do próprio mercado informal.

A lógica de formação dos preços no sub-mercado de loteamentos informais obedece a uma composição de fatores que, somados, definem o preço final dos lotes informais. Grosso modo, podemos listar os seguintes fatores determinantes dos preços no sub-mercado informal de loteamentos:

1. Fator ricardiano clássico vinculado aos fatores dos custos de fracionamento da gleba. Assim, as características topológicas e topográficas determinam custos de fracionamento diferenciados que serão incorporados no preço final do lote informal.

2. Fator thuneniano de localização. $\mathrm{O}$ fator localização do loteamento em relação à sua acessibilidade e à centralidade ponderada pelos meios de transporte disponíveis é um componente que também está incorporado no preço final do lote.

3. Fator de antecipação de infra-estrutura e de serviços futuros. O loteador, ao buscar lotes sem infra-estrutura urbana e não os disponibilizar para os seus eventuais compra- 
dores, antecipa que o poder público assumirá essas atribuições no futuro. Assim, os loteadores antecipam o valor futuro de uma área infra-estruturada pelo poder público e cobram hoje o que será ofertado no futuro. Esse ganho de antecipação varia em função dos cálculos de antecipação do tempo médio que o poder público levará para disponibilizar a infra-estrutura e os serviços urbanos básicos. Como veremos adiante, o fator de antecipação será um dos componentes mais importante do ganho de fracionamento da gleba, e conduz os loteadores a buscarem glebas baratas e com poucas acessibilidades e infra-estrutura, pois esse fato permite uma margem maior de ganho de antecipação pelo agente que fraciona a gleba. Em termos espaciais, isso significa uma busca contínua de novas áreas periféricas, portanto, um deslocamento recorrente da fronteira urbana ocupada a partir do uso urbano (ou peri-urbano) informal.

4. Fator de ajuste de mercado. Esse fator é um multiplicador ou redutor dos preços em função da concorrência oligopolista entre os loteadores e/ou outros sub-mercados informais e formais. A relativa opacidade ou transparência do mercado de lotes informais pode servir de ponderador desses redutores e multiplicadores, pois quanto mais opaco for o mercado em termos informacionais, menor o peso desse fator na determinação do preço final.

5. Fator de facilidade e de flexibilidade nos termos de contratação de créditos informais. A maior facilidade e flexibilidade no acesso a um lote a partir de contratos informais de endividamento familiar (crédito) gera juros (ou proto-ganho financeiro) de natureza informal. Esses juros informais não estão vinculados às taxas básicas de crédito da economia formal (taxa de juros fixada pelo Banco Central e praticada pelos agentes financeiros formais), mas serão incorporados ao preço final do lote.

Poderíamos agregar os fatores de natureza macro ou meso econômica, tais como volume de emprego, distribuição de renda, etc. Porém, esses fatores, em geral, apenas deslocam para cima ou para baixo o gradiente dos preços relativos do solo (Abramo, 2001). Em nossa perspectiva de relacionar o funcionamento do mercado de solo (formal e informal) com a produção da forma urbana, o importante são os preços relativos, isto é, a variação de um preço em uma localização-espacialidade particular aos outros preços-localização.

Assim, podemos sugerir que a estratégia dos loteadores informais será sempre a de buscar glebas com o intuito de fracioná-las minimizando os custos de fracionamento e maximizando os fatores que lhes permitam se apropriar de riquezas produzidas pela variação dos preços relativos do solo urbano. Nessas condições, a melhor estratégia do ponto de vista espacial é a busca de glebas baratas e sem infra-estrutura na franja da ocupação urbana do solo. O resultado, em termos de produção da forma de ocupação do solo da cidade, é uma tendência a extensificação contínua produzindo uma estrutura difusa da territorialidade da informalidade urbana. Em uma palavra, o funcionamento do submercado de loteamentos informais promove a extensificação do uso do solo e a sua resultante é a produção de uma forma difusa do território informal. Na cartografia da informalidade da cidade do Rio de Janeiro (Mapa 1), podemos visualizar de forma clara o sub-mercado de loteamentos promovendo um vetor de extensificação urbana. 
Mapa 1 - Localização dos loteamentos informais no Rio de Janeiro

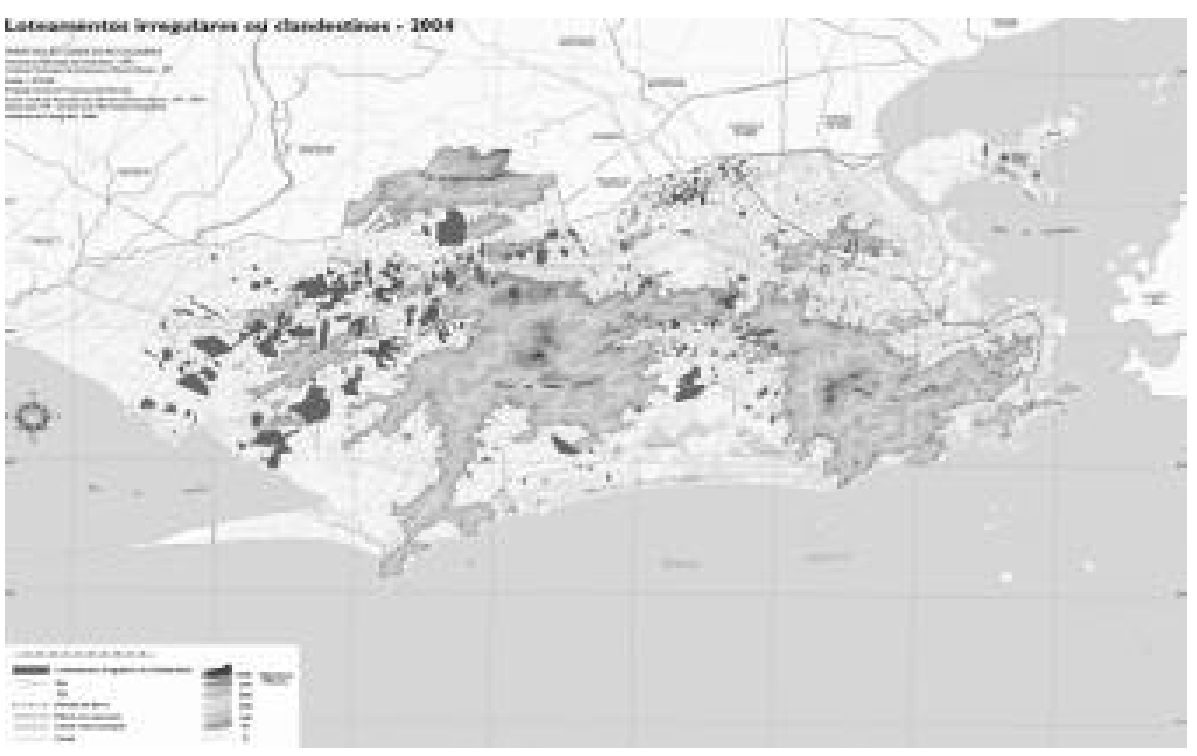

Fonte: Prefeitura da Cidade do Rio de Janeiro, 2005.

O sub-mercado das áreas populares informais consolidadas apresenta características bem distintas do sub-mercado de loteamentos. Vimos algumas delas no quadro comparativo que estabeleceu a distinção entre os dois sub-mercados informais e não vamos desenvolver essas diferenças nesse trabalho (ver Abramo, 2005; Abramo, 2009). ${ }^{3}$ Porém, queremos realçar que as externalidades endógenas positivas nos assentamentos populares informais consolidados são muito importantes na formação dos preços. Acreditamos que existem duas externalidades endógenas muito valoradas no mercado informal desses assentamentos. A primeira dessas externalidades denominamos de "externalidade de liberdade urbanística e construtiva”. Essa externalidade permite ao comprador de um imóvel informal exercer um direito de uso do solo (fracionamento e/ou solo criado) que não está regulado pelos direitos urbanísticos e de propriedade da legalidade do sistema jurídicopolítico do Estado.

A possibilidade de fazer um uso do solo de forma mais intensiva sem a mediação do Estado pode ser vista como uma liberdade para aquele que tem a posse, ou propriedade informal, de um lote e/ou edificação. Essa externalidade de liberdade urbanística será incorporada nos preços finais do mercado informal em áreas consolidadas e também será um atrativo para a demanda desse mercado (Abramo, 2005; Abramo, 2009). Utilizando a terminologia tradicional, podemos dizer que a liberdade urbanística e construtiva é uma vantagem comparativa importante em relação ao mercado formal de solo e, ao ser exercida, promove uma compactação nos assentamentos populares informais.

Uma segunda externalidade endógena positiva nos assentamentos populares informais consolidados é o que denominamos de "externalidade comunitária". Essa externalidade é o resultado de uma economia de reciprocidades em que as famílias têm acesso a bens e serviços a partir de relaçôes de Dom e Contra-Dom, nas quais não desembolsam valores monetários para aceder a certos bens e serviços (Caillé, 2000). A externalidade comunitária é sustentada por redes sociais e manifestam dinâmicas de proximidade organizada (Rallet e Torre, 2007) que permitem interações interfamiliares que reproduzem tem-
3 Em Abramo, 2009 (no prelo), desenvolvemos uma discussão detalhada e de natureza conceitual sobre as formas de funcionamento do mercado informal e as suas similitudes e diferenças em relação ao funcionamento do mercado formal. 
poralmente os laços de Dom e Contra-Dom. Esses laços estabelecem uma dinâmica de trocas baseada em relações de confiança e de lealdade (Pelligia, 2007).

Porém, a condição para entrar nessa economia de reciprocidades que garante $o$ acesso a bens e serviços sem comprometer uma parte dos recursos monetários familiares é morar em um assentamento popular informal e ter nele relações de reciprocidade. Assim, essa externalidade comunitária tende a ser capitalizada nos preços do solo e é capturada pelos vendedores do sub-mercado em APIs consolidados (Abramo, 2009). Para a discussão sobre a forma da territorialidade informal, insistimos que o fator proximidade é um elemento valorado pelo mercado informal de solo. A demanda nesse mercado busca as externalidades de liberdade urbanística e construtiva e a externalidade comunitária. O resultado concreto da prática (usofruto) da externalidade urbanística e construtiva é a compactação do território informal dos assentamentos populares com o fracionamento dos lotes, aumento da densificação predial e familiar e tendência a verticalização informal. Da mesma maneira, a existência e manutenção das externalidades comunitárias dependem da dinâmica de aglomeração territorial e dos laços sociais (redes) que se formam a partir desta aglomeração. Assim, as duas externalidades positivas mais importantes do sub-mercado informal de solo em áreas consolidadas promovem e se nutrem da compactação espacial.

Quadro 2 - Estratégias dos agentes dos sub-mercados informais de solo urbano

Economia das estratégias de localização dos

mercados informais de solo

1. Sub-mercado de assentamentos consolidados

ECONOMIA DA PROXIMIDADE

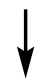

Estrutura compacta

2. Sub-mercados de loteamentos

ECONOMIA DE REDUÇÃO DE CUSTOS

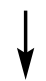

Estrutura difusa

Portanto, podemos levantar a hipótese que o funcionamento do sub-mercado informal nos APIs consolidados está estimulado por uma busca de efeitos de aglomeração e de compactação cujo resultado em termos de uso do solo é uma intensificação do uso do solo, portanto, uma compactação do território informal consolidado.

Um terceiro fator que incide no processo de compactação das áreas consolidadas informais é o crescimento nas duas últimas décadas dos custos de transporte, em particular o aumento dos gastos de transporte no orçamento familiar dos setores populares. $\mathrm{O}$ fenômeno das super-periferias revela o seu aspecto perverso e de iniqüidade social com o comprometimento crescente do orçamento familiar em custos de deslocamento. Uma resposta dos setores populares a esse fato pode ser a decisão de mudar seu domicílio para áreas com maior acessibilidade. Os dados censitários em muitos países revelam o que podería- 
mos chamar de um "retorno" dos pobres à centralidade e, na maior parte dos casos, a forma de retornar à centralidade é pela via do mercado informal nas áreas consolidadas.

Como vimos antes, o sub-mercado informal nas áreas consolidadas se divide em dois sub-mercados: o sub-mercado de comercialização (compra e venda de lotes, casas e apartamentos) e o sub-mercado de locação. Na impossibilidade de ocupar solo em áreas centrais e na impossibilidade de ter acesso ao solo formal, o mecanismo social de retorno dos pobres à centralidade será o mercado informal de comercialização e de locação. Resultados de pesquisas recentes sobre os mercados informais revelam a importância do sub-mercado de locação informal como forma de provisão habitacional para os setores populares (Abramo, 2007b). A tabela abaixo revela que em muitas cidades latino-americanas o submercado dominante nas áreas populares informais é o de locação.

Tabela 1 - Tipo de sub-mercado residencial nos APIs predominantes, 2006

\begin{tabular}{ll}
\hline País & Sub-mercado \\
\hline Argentina & Aluguel \\
Colômbia & Aluguel \\
México & Comercialização \\
Peru & Aluguel/Comercialização \\
Venezuela & Aluguel \\
Brasil & Comercialização \\
\hline
\end{tabular}

Fonte: Abramo, 2006/Infomercado.

Vemos que em Bogotá, Caracas e em algumas metrópoles brasileiras, o mercado de locação é dominante e cumpre um papel importante no acesso dos pobres ao solo urbano. Não há a menor dúvida de que o crescimento do mercado informal de locação é um fenômeno recente e a oferta desse mercado é o resultado de um uso mais intensivo do solo nos assentamentos consolidados. A oferta de locação informal, em geral, resulta de fracionamentos e/ou extensão da unidade residencial ou da subdivisão do lote original com edificação. Nos dois casos, a resultante é um uso mais intensivo do solo, portanto, uma compactação dos assentamentos informais.

O caso do Rio de Janeiro é bastante representativo desse crescimento. Em pesquisa realizada em 2002 (Abramo, 2003b), verificamos que a participação do mercado de locação informal representava $15 \%$ do mercado de solo nos assentamentos populares informais consolidados. Em apenas quatro anos, em 2006, essa participação passou a ser de 29,0\% e a locação informal cresceu em praticamente todos os assentamentos (favelas) pesquisados (Abramo, 2007b). Quando vemos a distribuição do tipo de produto dominante no mercado de locação, constatamos que os imóveis mais procurados são aqueles de apenas um quarto. A predominância de pequenas unidades habitacionais no mercado informal de locação alimenta a tendência de compactação informal. Assim, há dois movimentos que alimentam o processo de compactação via mercado de locação informal. O primeiro é a transformação de alguns moradores dos assentamentos em locadores informais, fracionando suas moradias e/ou lotes para atender a crescente demanda de locatários em áreas informais consolidadas. O segundo movimento é a preferência dos locatários informais por pequenas unidades em função da sua reduzida capacidade aquisitiva. Em geral, essas moradias de locação informal apresentam uma forte densidade domiciliar, e sugere uma precarização do precário (Abramo, 2007b). Tanto o movimento da oferta de locação informal quanto da demanda potencializam a tendência de compactação das áreas informais consolidadas. 
Tabela 2 - Produto dominante do mercado de locação por país, 2006

\begin{tabular}{ll}
\hline País & Sub-mercado \\
\hline Argentina & 1 quarto $(89,8 \%)$ \\
Brasil & 1 quarto $(79,4 \%)$ \\
Colômbia & 2 quartos $(42,7 \%)$ \\
México & 2 quartos $(42,2 \%)$ \\
Peru & 1 quarto $(56,2 \%)$ \\
Venezuela & 1 qto $(40,3 \%) / 2$ qtos $(38,4 \%)$ \\
\hline
\end{tabular}

Fonte: Abramo, 2006/Infomercado.

A explicação do crescimento do mercado de locação informal está associada à precarização do mercado de trabalho, mas também a uma dinâmica inter-generacional em que a capacidade de poupança familiar é praticamente inexistente e o capital inicial necessário para adquirir um lote ou casa precária simplesmente não existe. $\mathrm{O}$ depoimento de uma chefe de família em Florianópolis retrata de forma exemplar essa situação (Sugai, 2007):"eu pago aluguel, pago mais da metade do meu salário, e o pessoal daqui diz que com esse dinheiro eu podia deixar o aluguel e pagar um lote lá longe, mas eu pago o lote e vou morar onde? Eu não tenho dinheiro para colocar uma casa de pé. Assim, tenho que ficar no aluguel, mesmo sendo tão caro".

O depoimento nos revela a incapacidade de poupança familiar para comprar um lote e iniciar um processo de edificação progressiva, clássico nos loteamentos informais populares, mas também deixa claro que uma das razóes para essa incapacidade de poupança familiar está relacionada com os altos preços dos aluguéis em relação aos seus rendimentos. Em outras palavras, temos o paradoxo do mercado informal de locação: ao praticar preços relativos altos, garante a sua demanda, que não é capaz de saltar para o outro sub-mercado informal de solo, o mercado de loteamentos.

Tabela 3 - Preços médios dos aluguéis em Salários Mínimos por país, 2006

\begin{tabular}{lc}
\hline País & Aluguel \\
\hline Brasil & 0,75 \\
Argentina & 0,24 \\
México & 0,55 \\
Venezuela & 0,45 \\
Colômbia & 0,68 \\
Peru & 0,08 \\
\hline
\end{tabular}

Fonte: Abramo, 2006/Infomercado.

Outro fator que alimenta a oferta de locação informal é a alternativa que as famílias pobres encontram para complementar seu orçamento familiar fracionando a sua unidade habitacional para fins de locação. Ademais desse fator, podemos sugerir que também temos um estímulo de mercado. No mercado formal, o valor de locação de um imóvel tende a ser inferior a $1 \%$ do valor de comercialização deste imóvel. Na tabela abaixo, vemos que as taxas de rentabilidade da locação informal na América Latina são muito superiores ao valor de referência dos bairros formais. 
Tabela 4 - Rentabilidade do mercado de locação informal - relação entre preços médios de locação sobre os preços médios de compra em \% por país, 2006

\begin{tabular}{lc}
\hline País & Aluguel \\
\hline Brasil & 2,37 \\
Argentina & 2,28 \\
México & 1,09 \\
Venezuela & 0,70 \\
Colômbia & 2,10 \\
Peru & 1,51 \\
\hline
\end{tabular}

Fonte: Abramo, 2006/Infomercado.

Nesse sentido, podemos dizer que há um estímulo de mercado na conversão de espaços familiares em oferta no mercado de locações informais. Esse estímulo perverso, pois reduz o indicador de habitabilidade nas áreas informais, representa também um estímulo à compactação nos assentamentos consolidados informais. Em outras palavras, do ponto de vista da forma do uso do solo, o crescimento do mercado de locação nas áreas populares informais potencializa a tendência do mercado informal em produzir uma compactação dessas áreas.

Nos mapas abaixo, vemos a cartografia dos dois grandes sub-mercados informais de solo na cidade do Rio de Janeiro. Podemos visualizar uma clara distinção espacial entre os sub-mercados de loteamento e o sub-mercado de solo nas áreas consolidadas. O primeiro se localiza na periferia urbana, enquanto o segundo, nas áreas mais centrais da cidade. Porém, o elemento importante desse mapa é aquele que sinaliza que o funcionamento do sub-mercado nos assentamentos consolidados produz uma estrutura compacta, enquanto o funcionamento do sub-mercado de loteamento promove uma estrutura difusa.

Mapas 2 e 3 - Cartografia dos dois sub-mercados informais de solo na Cidade do Rio de Janeiro

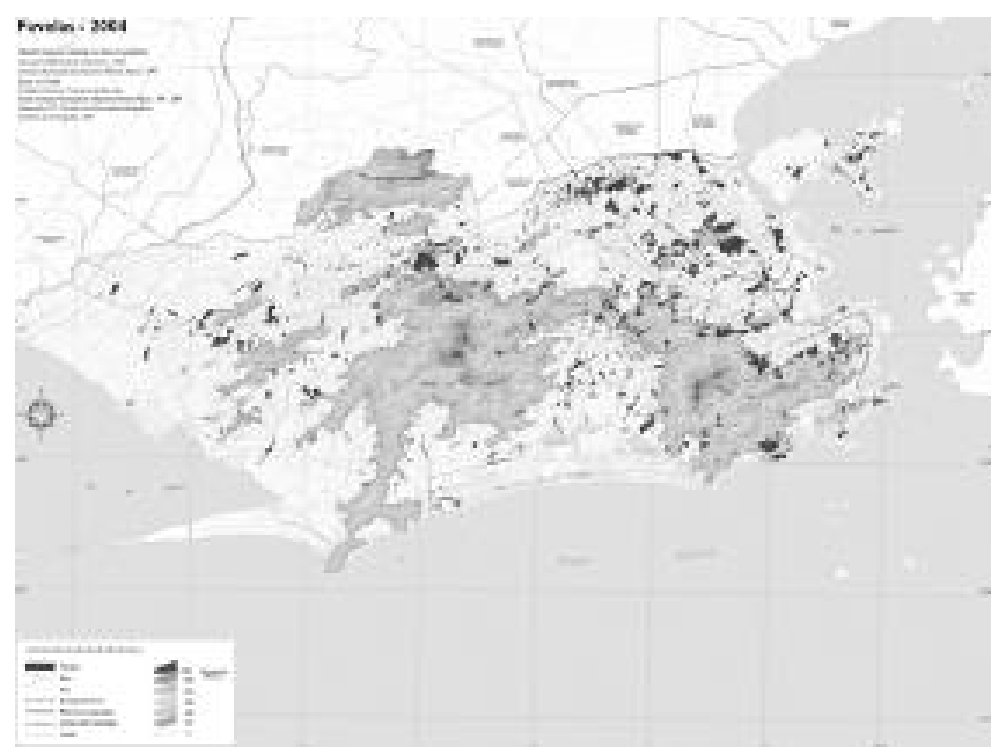




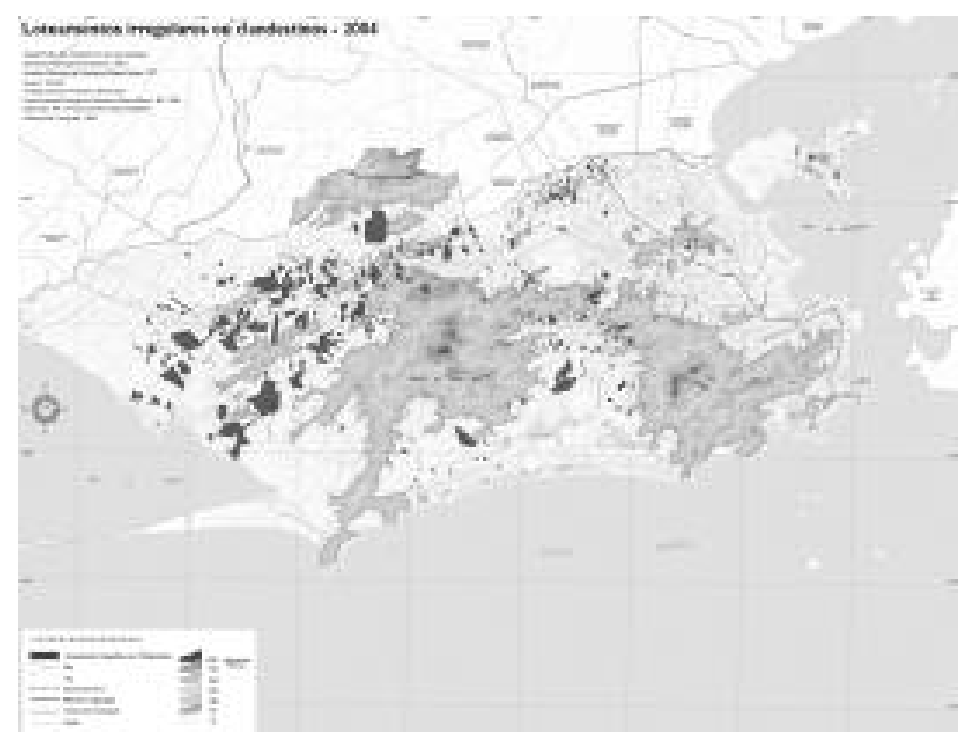

Fonte: Prefeitura da Cidade do Rio de Janeiro, 2005.

A conclusão, em termos de produção da territorialidade informal que chegamos ao verificar as formas de funcionamento do mercado informal de solo, é evidente: o submercado em APIs consolidados promove uma "cidade informal" compacta, enquanto o sub-mercado de loteamento produz uma "cidade informal" difusa. Isto é, o funcionamento do mercado informal de solo para os setores populares produz uma estrutura urbana COM-FUSA, ou seja, é o mercado informal de solo que produz simultaneamente uma estrutura compacta e difusa.

\section{O CÍRCULO PERVERSO DA RETROALIMENTAÇÃo DOS DOIS SUB-MERCADOS INFORMAIS DE SOLO}

O fato de os dois sub-mercados informais produzirem uma estrutura COM-FUSA do uso do solo urbano informal é grave, pois promove uma dupla precarização do habitat e da reprodução da vida popular. O mercado informal, ao promover um território cada vez mais difuso, impõe custos de transporte crescentes aos trabalhadores que vivem nesses loteamentos, mas, quando o mesmo mercado produz uma compactação nos assentamentos consolidados, ele causa uma precarização do habitat popular com o aumento de densidade (predial e domiciliar) e verticalização com todas as implicações nos indicadores de habitabilidade (escassez de ar, sol, etc.) que essa compactação promove. Em termos macrosociais, a existência e a continuidade do mercado informal de solo estão vinculadas à desigualdade na distribuição de renda e à incapacidade do poder público de promover uma oferta massiva e regular de moradias. Porém, gostaríamos de sublinhar um outro elemento que não está necessariamente relacionado com o aumento da precariedade laboral ou a incapacidade de ação pública, mas que serve de motor e alimenta o funcionamento dos dois sub-mercados informais de solo.

Ao caracterizar o funcionamento dos dois sub-mercados informais de solo, vemos que há uma tendência de retroalimentação entre eles, na qual o sub-mercado de loteamento gera uma demanda para o sub-mercado nas áreas consolidadas, e vice-e-versa, este sub-mercado também produz uma demanda para o outro sub-mercado. Temos uma 
forma de funcionamento dos sub-mercados informais de solo em que um sub-mercado promove a demanda do outro de forma contínua e circular. Essa dinâmica de demandas de solo informal que se auto-alimentam mutuamente cria um sistema fechado que, ao criar efeitos de retroalimentação, reproduzem em escala crescente a estrutura COM-FUSA da territorialidade popular informal.

Diagrama 1 - Círculo perverso de retroalimentação dos dois sub-mercados informais de solo

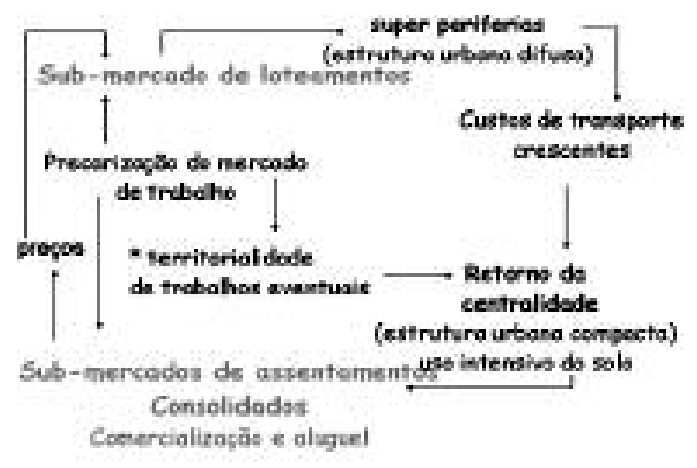

No diagrama acima, esquematizamos o circuito perverso de retroalimentação dos dois sub-mercados informais de solo. Vemos que o funcionamento do sub-mercado de loteamentos informais, ao promover uma cidade cada vez mais difusa, impóe um custo de transporte crescente à população que decide morar em uma periferia cada vez mais distante do centro. Da mesma forma, a precarização do mercado de trabalho e o crescimento da participação de trabalhos eventuais exigem a presença física desse trabalhador em alguma centralidade, impondo um custo de deslocamento que não será necessariamente compensado com o rendimento diário do seu trabalho. Uma saída para essas famílias é retornar à centralidade. Mas, para tanto, eles devem retornar pela porta do mercado informal em áreas consolidadas, seja pela "mão" do mercado de comercialização, seja pela "mão" do mercado de locação. Assim, o funcionamento do sub-mercado de loteamentos produz uma demanda para o sub-mercado nas áreas consolidadas. Mas, o crescimento da demanda no sub-mercado em áreas consolidadas não pode ser respondido com uma maior oferta em razão da sua relativa inelasticidade.

Assim, a reação do mercado é via preços, isto é, os preços tendem a crescer. Com isso, temos um aumento de intenções de famílias de disponibilizarem seus imóveis ou lotes nas áreas consolidadas e se capitalizarem (descapitalizarem) para comprar um lote na periferia e construir moradias com melhores (piores) condiçōes de habitabilidade. Outra vez, o funcionamento de um sub-mercado informal alimenta a demanda do outro; nesse caso, o sub-mercado nas áreas consolidadas gerou uma demanda para o sub-mercados na periferia. Esse efeito de retroalimentação é perverso, pois produz uma estrutura urbana informal mais compacta nas áreas consolidadas e mais difusa nas franjas urbanas; a "cidade informal" COM-FUSA é portadora de uma precarização do habitat popular, como também de uma perda de ineficiência no uso do solo urbano. Também podemos afirmar que o circuito perverso de retroalimentação promove um crescimento dos preços do mercado informal de solo, incrementando as distribuições regressivas da riqueza capturada na forma de valorização do solo. 


\section{O TERRITÓRIO COM-FUSO FORMAL ${ }^{4}$}

O mercado imobiliário é o principal vetor de estruturação do uso residencial do solo formal das grandes cidades latino-americanas. Ao contrário do mercado informal, as instituições reguladoras desse mercado estão inscritas no ordenamento do sistema jurídico-político do Estado. Porém, o mercado imobiliário tem uma série de peculiaridades que o tornam um mercado particular em relação a outros mercados da economia capitalista. As três principais características distintivas desse mercado são: a imobilidade territorial do bem imobiliário; o seu alto valor individual e o seu longo período de depreciação. Cada uma dessas três características coloca um problema para a reprodução do capital imobiliário. A imobilidade impede que esse bem, produzido sobre um suporte locacional específico, seja eventualmente descolocado a um outro mercado-localização (bairro, cidade, país). O alto valor individual do bem imóvel impõe que a demanda assuma um comprometimento dos seus rendimentos familiares futuros, pois a aquisição do bem imóvel, em geral, envolve uma decisão de endividamento familiar. E o longo período de depreciação, em média de 70 anos, é um fator que condiciona no curto e no médio prazo o retorno da demanda atendida ao mercado condicionando, portanto, a demanda habitacional a fenômenos demográficos (ciclo familiar, migrações, etc.).

Além dessas características, o mercado imobiliário formal nas grandes cidades latino-americanas está altamente segmentado em termos de capacidade de compra da demanda. Essa segmentação de capacidade aquisitiva e solvabilidade da demanda é expressão da desigualdade na distribuição da riqueza no mercado imobiliário. A forma dos capitais imobiliários de se libertarem dessas restrições estruturais do mercado imobiliário na América Latina foi a constituição de um mercado imobiliário altamente segmentado. Essa segmentação responde a duas ordens de motivos diferentes. Do ponto de vista da oferta, isto é, dos capitais imobiliários, a segmentação da demanda permite uma redução dos riscos e das incertezas dos empreendimentos imobiliários.

Do ponto de vista da demanda (unidades familiares), a segmentação do mercado imobiliário garante uma relativa homogeneidade socioespacial do seu entorno residencial. Em outras palavras, uma estrutura de oferta residencial segmentada em termos socioeconômicos promove uma estrutura espacial segmentada em termos socioespaciais. Essa estrutura residencial segmentada (ou segregada, segundo alguns autores) se manifesta como um mecanismo de "distinção espacial hierarquizada" que reitera espacialmente as divisões de classe e de estratificação socioeconômica da sociedade (Bourdieu, 1994). Assim, a segmentação da oferta promovida pelos capitais e a busca de segmentação (distinção espacial) da demanda se articulam funcionalmente e definem uma forma de atuação dos capitais imobiliários nas grandes metrópoles latino-americanas. Essa dinâmica de valorização dos capitais imobiliários produz o que denominamos de uma cidade caleidoscópica (Abramo, 2007a).

Em trabalhos anteriores, discutimos de forma conceitual e empírica (Abramo, 2001) as motivações da demanda residencial no mercado formal, e concluímos que o fator determinante das escolhas residenciais é motivada por uma busca de distinção socioespacial, porque as famílias desejam estar próximas aos seus próximos. O desejo de proximidade com os seus próximos se concretiza em uma externalidade de vizinhança que preferimos chamar de convenção urbana (Abramo, 2007a). Em uma sociedade estratificada, esse padrão de comportamento de desejar estar próximo dos seus próximos produz uma cascata de movimentos de rejeição dos não-próximos do alto da pirâmide social para baixo. As- 
sim, as convenções urbanas são hierarquizadas e servem de mecanismo cognitivo que garante a estrutura segmentada e hierarquizada das externalidades de vizinhança, portanto, da estrutura socioespacial urbana segmentada (segregada) e desigual.

Diagrama 2 - A busca de distinção socioespacial: a externalidade de vizinhança

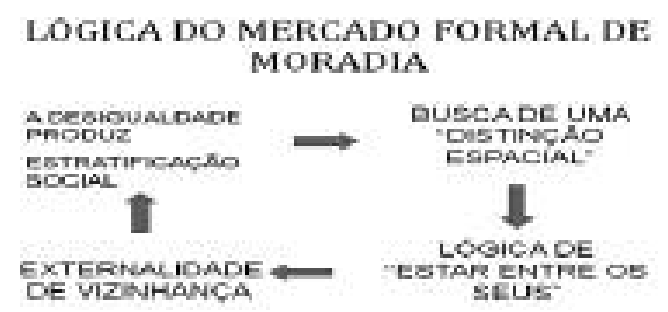

A convenção urbana é uma externalidade de vizinhança que não necessariamente está ancorada em uma territorialidade específica; ela não está definida por fatores naturais, mas sim pelo caráter de interação socioespacial de setores do mesmo estrato social (ou cultural, étnico, etc.). Essa característica da externalidade de vizinhança ser um processo de emergência e de manutenção de relaçóes de interação socioespacial será utilizada pelos capitais imobiliários que desejam renovar o segmento de demanda que habitualmente constituem a sua demanda solvável. Para atrair novamente ao mercado imobiliário a mesma demanda, os capitais devem superar a barreira do tempo de depreciação física das edificações.

A forma para realizar essa operação é a mesma utilizada nos outros setores de bens duráveis, isto é, promover de forma contínua a diferenciação de produtos, de tal forma que permita uma depreciação fictícia dos bens duráveis. Essa depreciação fictícia de uma parte dos estoque imobiliários promove um mercado secundário que será determinante na manutenção da liquidez do mercado de imóveis novos. Isto é, a depreciação fictícia deve ser de tal forma que os imóveis depreciados tenham ainda vida útil e, sobretudo, representem uma opção de moradia para estratos sociais inferiores aos que residiam anteriormente nessa espacialidade. Mas, no caso do mercado imobiliário, temos duas dificuldades para a utilização dessa prática empresarial.

A primeira diz respeito à imobilidade espacial dos bens. Assim, a depreciação fictícia significa um deslocamento espacial do vetor de atuação dos capitais imobiliários e uma impossibilidade de eliminação do mercado dos bens depreciados de forma fictícia. Esse segundo problema foi resolvido com o mercado secundário, em que a faixa temporal dos produtos desse mercado secundário são muito superiores aos dos outros mercados secundários de bens duráveis (automóveis, eletrodomésticos, etc.). A existência do mercado secundário inclusive reduz os problemas relacionados aos altos valores individuais, pois a maior parte das transações no mercado imobiliário formal são contratos casados, em que o eventual comprador de um imóvel deve vender, ou vendeu, um outro imóvel. Em outras palavras, a maior parte dos compradores de bens imobiliários também são (ou foram) vendedores no mercado secundário.

Esse fato introduz uma dificuldade para as estratégias capitalistas de diferenciação dos produtos imobiliários, pois uma desvalorização desmedida (depreciação fictícia) do estoque residencial existente pode reduzir a liquidez do mercado primário e inviabilizar a operação de diferenciação do produto imobiliário. Assim, os capitalistas imobiliários, nas suas estratégias de uso do solo formal, devem procurar desvalorizar o estoque para alguns 
(aqueles que buscam atrair como demanda solvável), mas essa desvalorização deve representar uma valorização para aqueles que garantem a liquidez do mercado primário, ou seja, para os setores imediatamente inferiores na hierarquia de estratificação social. Assim, toda desvalorização fictícia do estoque promovida pela diferenciação do produto e/ou espacial é uma depreciação relativa, pois também representa uma possibilidade de valorização locacional e imobiliária para outros estratos sociais.

Como esse efeito está encadeado para trás, pois quem compra sempre vende, a operação de diferenciar os produtos imobiliários se transforma em uma cadeia urbana de desvalorizações-valorizações imobiliárias em que a atuação do capital imobiliário em um pequeno segmento do mercado pode promover uma modificação mais ampla na cartografia socioespacial (Abramo, 2007a).

Do ponto de vista da movimentação socioespacial, temos dois elementos críticos importantes. $\mathrm{O}$ primeiro desses elementos é que uma diferenciação do produto imobiliário envolve necessariamente um deslocamento espacial da oferta: oferecer um produto diferente em uma espacialidade diferente. Mas, aqui temos o surgimento do segundo elemento crítico, pois quando os capitalistas imobiliários pretendem deslocar espacialmente a sua oferta, devem deslocar espacialmente uma parte das famílias que desejam desfrutar da externalidade de vizinhança (estar entre os seus e ser/ter uma distinção socioespacial em relação aos outros). Assim, uma depreciação fictícia do estoque imobiliário, uma diferenciação da oferta em relação ao estoque existente, também exige um deslocamento de uma externalidade de vizinhança. Nesse sentido, toda operação de destruição fictícia de uma parte do estoque imobiliário, ao ter que recriar uma externalidade de vizinhança, é de fato uma inovação espacial. E essa inovação espacial, ainda que procure deslocar somente uma pequena parcela da demanda, envolve uma série de efeitos em cascata de deslocamentos domiciliares com o necessário deslocamento espacial da externalidade de vizinhança, como podemos ver no diagrama abaixo.

Figura 1 - Estratificação socioespacial do mercado formal de moradias e lógica dos deslocamentos em cascata

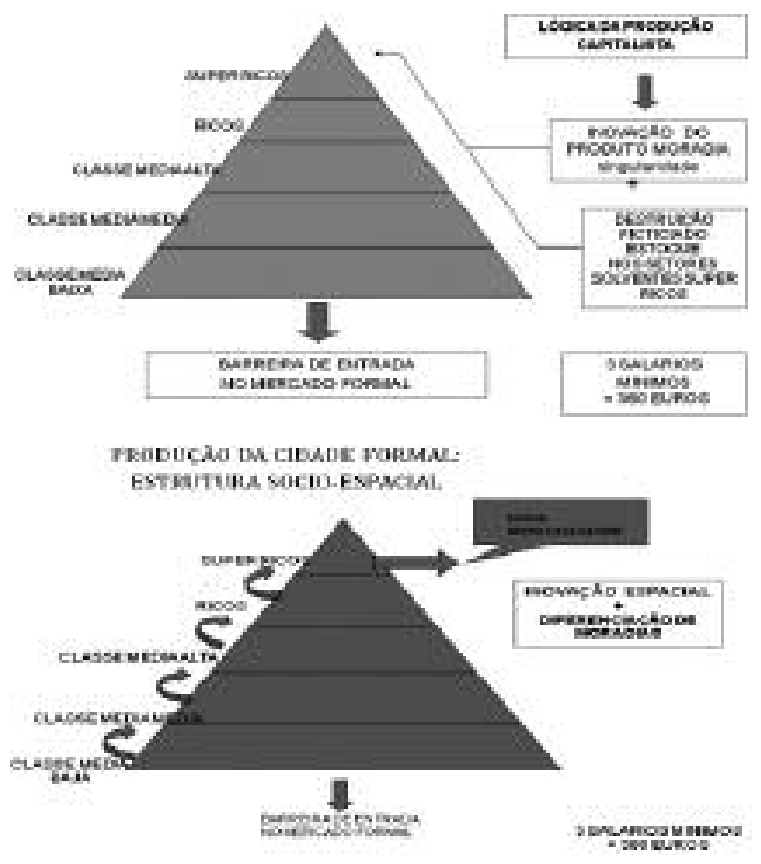


O efeito urbano desse movimento de deslocamentos domiciliares e de externalidades de vizinhança promovido por uma pequena intervenção de diferenciação do produto para um segmento restrito do mercado se assemelha a um caleidoscópio no qual um pequeno deslocamento de um cristal reconfigura toda a imagem. Assim, podemos dizer que o funcionamento do mercado imobiliário formal tem uma dinâmica caleidoscópica em que a ação localizada de alguns capitais pode gerar uma série de efeitos correlatos em cascata e, na maior parte das açôes, do alto da pirâmide social para baixo (Abramo, 2007a).

Mas o leitor deve estar se perguntando a razão dessa digressão, pois o nosso interesse nesse trabalho é o de discutir a produção da forma espacial das cidades latino-americanas. A razão dessa digressão está relacionada ao ato gerador do movimento caleidoscópio das mudanças de uso do solo urbano formal. $\mathrm{O}$ ato que promove esse movimento caleidoscópico é uma inovação espacial. Como dissemos anteriormente, essa inovação espacial é a articulação de um novo produto imobiliário em uma nova espacialidade urbana. Mas, deslocar espacialmente uma demanda também impõe um deslocamento espacial da convenção urbana à externalidade de vizinhança. Somente podemos identificar uma inovação espacial, promovida pelos capitais imobiliários, quando temos esses dois componentes associados. Em geral, a possibilidade de articular esses dois elementos está associada a uma operação de certa escala em relação ao uso do solo urbano. A escala da operação é importante, pois exige a atuação de vários capitais imobiliários, portanto, alguma forma de coordenação da sua atuação. Assim, essa inovação desvela em termos espaciais um dos paradoxos do funcionamento do mercado, isto é, o seu caráter concorrencial e de decisões individuais e autônomas, mas que exige alguma coordenação para concretizar o resultado antecipado: inovação do produto imobiliário e/ou habitat com um deslocamento espacial da externalidade de vizinhança.

Esse duplo movimento revela o ambiente de incerteza urbana em que as decisões locacionais (dos capitais e das famílias) são tomadas (Abramo, 2007a). Uma forma de minorar essa incerteza em relação às inovações espaciais é a de promover essas inovações com uma estratégia locacional de contigüidade espacial. Assim, nas últimas décadas, podemos sugerir que as inovaçóes espaciais nas grandes cidades latino-americanas se manifestaram a partir de um processo de extensificação da "cidade" formal com a contínua promoção de inovações espaciais para os estratos superiores da pirâmide da distribuição de renda. Em termos da estrutura urbana, essa estratégia de atuação dos capitais imobiliários é promotora de uma cidade de estrutura difusa. Como ilustração dessa tendência, podemos ver a evolução do uso do solo do vetor mais rico da cidade do Rio de Janeiro, onde este segmento de demanda solvável é sistematicamente deslocado espacialmente, promovendo uma dinâmica de extensificação da cidade formal (cidade difusa). 
Mapa 4 - Deslocamento urbano das inovações espaciais na cidade do Rio de Janeiro

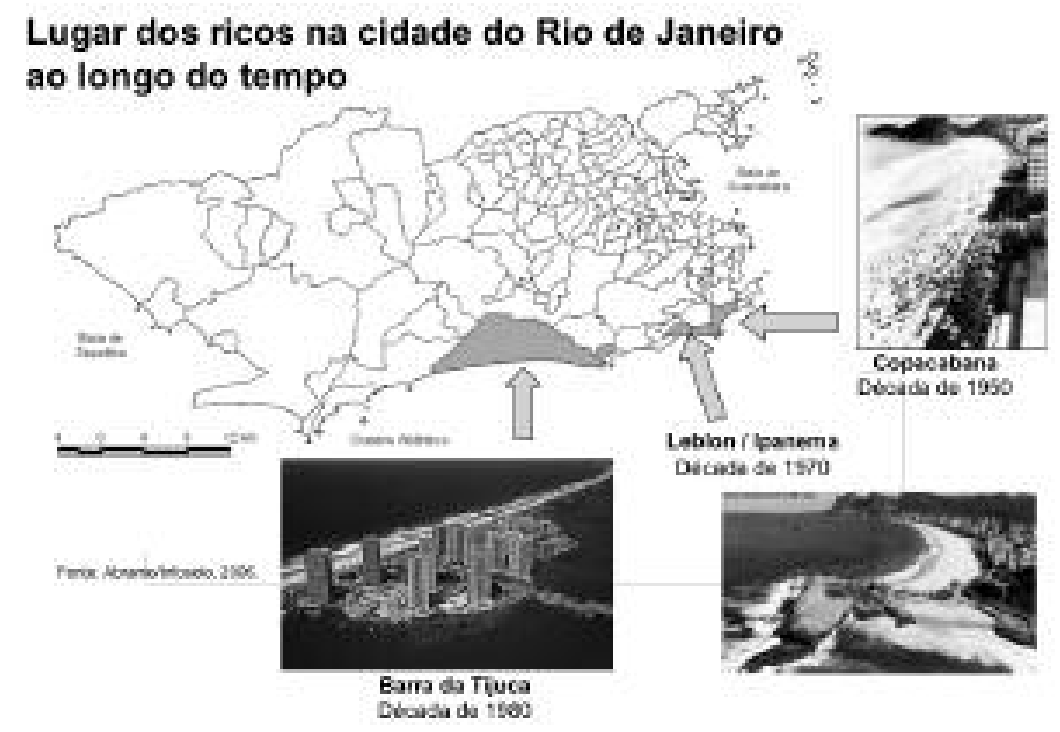

Mas esse processo de inovação espacial, promotor da estrutura formal difusa, tem o seu reverso. E o seu reverso é um processo de compactação da estrutura de uso formal do solo. Identificamos dois efeitos de compactação associados às estratégias de inovação espacial. O primeiro efeito de compactação nos remete ao fato de o estoque depreciado de forma fictícia por uma inovação espacial ser ocupado por famílias de estrato inferior de renda. Em geral, esse movimento de substituição domiciliar produz um efeito de crescimento da densidade domiciliar, pois a preços do solo superiores, as famílias tendem a consumir menos espaço urbano, e a conseqüência seria optarem por unidades habitacionais menores do que as que deixaram. Assim, as famílias tenderiam a substituir espaço domiciliar por melhor acessibilidade e/ou um movimento ascendente na hierarquia de representação socioespacial da cidade.

Mas o crescimento da densidade domiciliar também vem acompanhado de um crescimento na densidade predial, em função de os lotes remanescentes nessa localização urbana terem agora uma lógica de uso do solo mais intensivo. A oferta de imóveis novos se adapta à demanda potencial de um estrato de renda familiar inferior sem necessariamente reduzir os preços do solo. Assim, o ajuste será oferecer unidades habitacionais com um tamanho médio inferior ao do estoque existente, produzindo um crescimento da densidade predial. Como enfatizamos antes, esse processo de substituição não se restringe a uma única localização; ele se replica em um conjunto de outras localizações urbanas pelas mesmas razões. Ou seja, para uma família adquirir um novo imóvel, ela vende um outro imóvel. Esse imóvel tende a ser adquirido por uma família de estrato imediatamente inferior de renda, e se repete o processo de compactação que acabamos de descrever.

Assim, o resultado do efeito em cascata dessa dinâmica de substituição de consumo de espaço domiciliar por melhor posicionamento na hierarquia de acessibilidades e/ou socioespacial e de crescimento na intensidade do uso imobiliário do solo, que se inicia nos estratos mais altos de renda e transborda para os estratos mais baixos, é um amplo processo de compactação da estrutura de uso do solo da cidade formal.

$\mathrm{O}$ segundo efeito de compactação do uso do solo nos remete às estratégias de imitação que toda inovação exitosa tende a gerar no comportamento da oferta capitalista. Nes- 
se sentido, uma inovação espacial, que efetivamente promove uma desvalorização fictícia do estoque e desloca espacialmente uma externalidade de vizinhança, tende a ser imitada por outros capitais imobiliários. Mas o processo de mimetismo econômico de imitação da inovação exitosa deve ser replicado para famílias de estratos de renda inferiores, pois somente assim a imitação ganha o caráter de uma inovação relativa. Mas, a utilização de uma inovação que foi concebida para estratos superiores de renda para uma demanda de estratos inferiores deve ser redefinida em termos escalares e, sobretudo, rentabilizar o uso do solo com um uso mais intensivo. Em outras palavras, a imitação, ao induzir o uso mais intensivo do solo, promove uma compactação da estrutura urbana formal. No mapa da cidade do Rio de Janeiro abaixo vemos que a difusão/imitação de uma inovação tende a se direcionar para vários vetores de vertebração da cidade.

O resultado agregado da dinâmica de valorização imobiliária será um duplo processo espacial. De um lado, a inovação espacial busca uma diferenciação do estoque imobiliário, mas o seu êxito induz ao mimetismo e à reprodução da inovação espacial em outras localizações urbanas, produzindo o seu contrário, ou seja, uma homogeneização do estoque imobiliário residencial. De outro lado, a inovação espacial se realiza promovendo uma estrutura difusa de cidade, mas os deslocamentos espaciais das externalidades de vizinhança e o processo de imitação desta inovação produzem justamente o seu contrário: uma estrutura urbana compacta.

Mapa 5 - O mimetismo das inovações espaciais no Rio de Janeiro

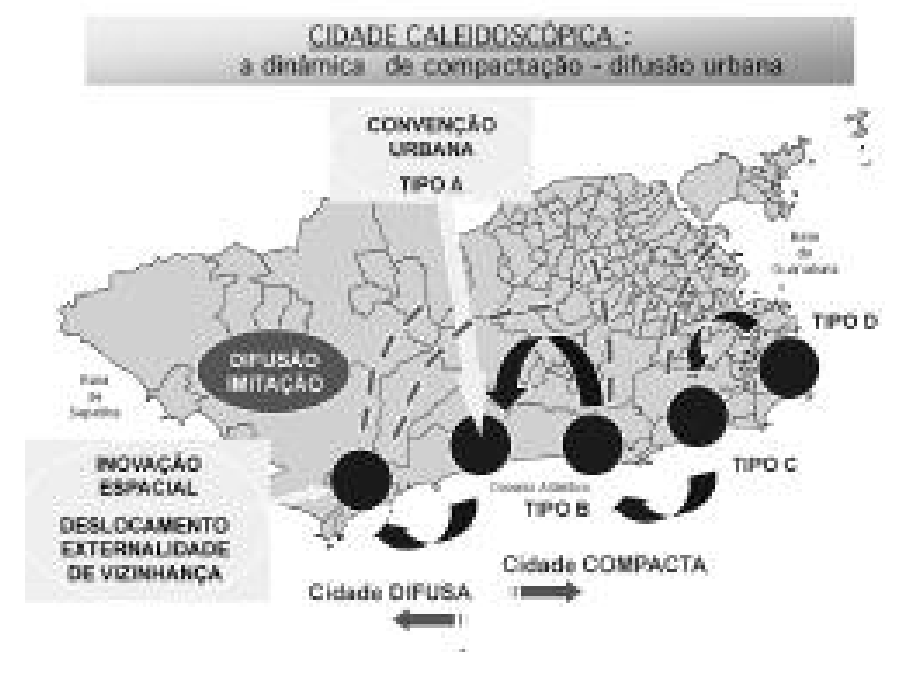

De fato a imitação de uma inovação espacial promove uma tendência de homogeneização do estoque residencial. Mas a homogeneização do estoque obriga os capitais imobiliários a introduzirem produtos diferenciados. Assim, enquanto a inovação promove uma diferenciação do estoque residencial, a sua imitação reafirma uma tendência contrária de homogeneização do estoque. Dessa maneira, a inovação produz uma forma urbana difusa, enquanto a imitação produz uma estrutura compacta. Outra vez, mas agora para a territorialidade formal da cidade, vemos que o funcionamento do mercado imobiliário produz uma estrutura urbana com uma forma de uso do solo COM-FUSA.

Da mesma maneira que encontramos uma lógica de retroalimentação da estrutura COM-FUSA do uso do solo informal, também temos um circuito de funcionamento do 
mercado formal em que a mão do mercado promove um circuito de retroalimentação da estrutura compacta e difusa. Em termos esquemáticos, o funcionamento do mercado imobiliário formal produz em termos espaciais um processo de polaridades que se reforçam mutuamente: a diferenciação promove a homogeneização, que estimula a diferenciação. Como podemos ver no diagrama abaixo, o resultado espacial do funcionamento desse mercado é o de uma estrutura de uso intensivo e extensivo do solo produzindo, do ponto de vista da estrutura urbana, uma cidade formal COM-FUSA.

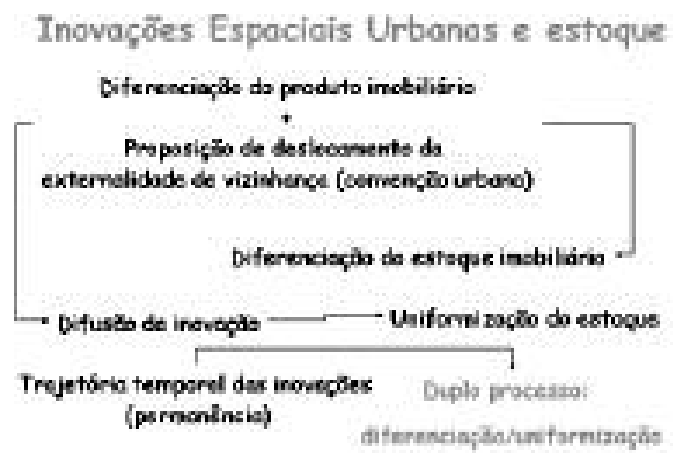

Concluímos propondo uma leitura do funcionamento do mercado imobiliário formal em que os efeitos retroalimentadores das estratégias dos capitais imobiliários e da demanda residencial produzem a produção e a reprodução de uma forma de uso do solo formal COM-FUSA. Além disso, o circuito de produção da estrutura COM-FUSA formal se alimenta dele mesmo, caracterizando um sistema fechado ou um sistema que se aproxima dos sistemas de auto-organização mercantil.

\section{CONCLUSÃO}

A conclusão desse trabalho exploratório sobre a relação entre o funcionamento do mercado de solo e a produção e reprodução da estrutura do uso do solo é a de alertar para os riscos do retorno do mercado como principal mecanismo de coordenação coletiva do uso do solo urbano. Como vemos na figura abaixo, tanto o mercado informal quanto o mercado formal de solo promovem um duplo movimento de compactação e difusão, produzindo um uso do solo de estrutura COM-FUSA nas grandes cidades latino-americanas.

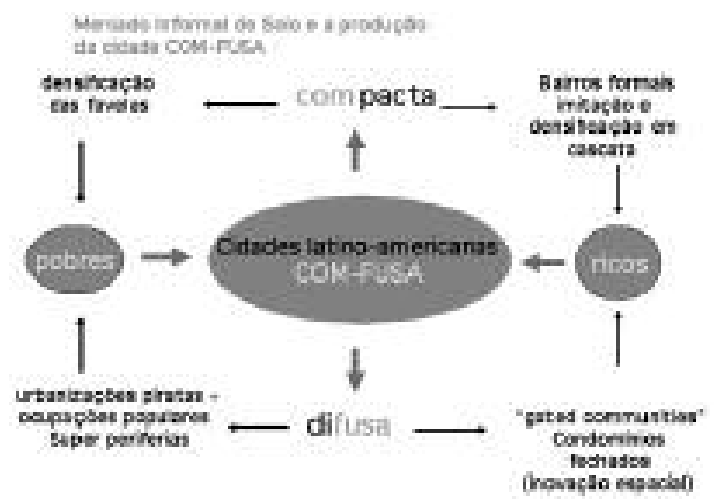


Não temos dúvidas de que numa cidade com uma forma COM-FUSA do uso do solo as exigências de coordenação e de controle público da liberdade de mercado são imprescindíveis para torná-la mais igualitária e mais justa do ponto de vista do acesso e da distribuição da riqueza urbana. Contra o retorno da mão inoxidável do mercado, procuramos demonstrar a imperiosa necessidade de lutar pelo retorno da ação pública de coordenação do uso do solo urbano. Uma ação pública renovada pela ampla participação popular em suas decisões e que supere a fórmula do planejamento urbano modernista em que o princípio da racionalidade instrumental delegue a poucos as decisões sobre a vida urbana de todos.

Poderíamos concluir com uma discussão sobre os impactos da estrutura COM-FUSA das cidades latino-americanas na formulação das políticas urbanas, mas decidimos terminar esse trabalho reproduzindo uma linda afirmação de Samuel Jaramillo (2007), ${ }^{5}$ em que ele enfatiza a necessidade de uma bússola e de um timão para controlar a fúria da mão inoxidável do mercado. Segundo as palavras de Samuel: "para orientarse en este mar embravecido de la ciudad caleidoscópica (COM-FUSA) no vale encomendarse al auxilio hipotético de alguna mano invisible caritativa (el mercado): son necesarios timón y brújula, es decir, se requiere de la acción política democrática, de nuevo de la planificación, y de la comprensión de conjunto de la dinámica urbana."

\section{REFERÊNCIAS BIBLIOGRÁFICAS}

ABRAMO, P. (2009). Favela e o capital misterioso: por uma teoria econômica da favela (no prelo)

ABRAMO, P. (2007a). A Cidade caleidoscópica. Rio de Janeiro: Bertrand do Brasil. . (2007b). Aluguel informal e acesso dos pobres à cidade. Cambridge-MA: Lincoln Institute of Land Policy. Versão preliminar.

- (2005). La ciudad latinoamericana y sus particularidades: mercado del suelo y estrutura urbana In: Los Desafios de una política de suelo en América Latina. Cidade do México-DF : PUEC/Unan, 2005, v.1, p. 76-103.

. (ed.) (2003a). A Cidade Informal. Rio de Janeiro: Sette Letras.

- (2003b). A dinâmica do mercado imobiliário e a mobilidade residencial nas

favelas do Rio de Janeiro: resultados preliminares. unpublished research report Rio de Janeiro: IPPUR-UFRJ.

. (2001). Mercado e Ordem Urbana. Rio de Janeiro: Bertrand do Brasil.

. (1999b). Formas de funcionamento do mercado imobiliário em favelas, unpublished research report. Brasília: CNPq.

ABREU, M. (1997), Evolução urbana do Rio de Janeiro. Rio de Janeiro: Ed. Zahar.

AGAMBEN, G. (2008). Che cos'é il contemporaneo? Roma: Nottetempo.

. (2004). Estado de Exceção. São Paulo: Boitempo.

ARENSBERG, H.; PEARSON, H.; POLANYI (eds) (1957). Trade and market in the early empires, economies in history and theory. New York: Free Press.

AZUELA, A. (1989). La ciudad, la propiedad y el derecho. México: El Colégio de México.

. (2001). Definiciones de informalidad. Cambridge-MA: Lincoln Institute of Land Policy, notas do curso "Regularización".

BAGNASCO, A. (1999). Tracce di comunita. Bolonha: Il Mulino.
5 Parágrafo extraído do comentário de Samuel Jaramillo do livro Cidade Caleidoscópica, de Abramo (2007), publicado na revista Territórios, ACIUR, Bogotá, Colômbia, 2007.

Pedro Abramo é doutor em Economia pela Ėcole des Hautes Etudes en Sciences Sociales, Paris, França. Professor do IPPUR/UFRJ

E-mail: pabramo@uol.com.br

Artigo recebido em fevereiro de 2008 e aprovado para publicação em outubro de 2008. 
BECKER, G. (1981). A treatise of the family. Cambridge: Harvard University Press. BOLTANSKY, L. ; THÉVENOT, L. (1991), De la justification: les economies de la grandeur. Paris: Galimard.

BOURDIE, P. (ed.) (1994). La Misére du monde. Paris: Seuil.

BRUNI, L. (2006). Reciprocitá. Dinamiche di cooperazione economia e società civile. Milão: Bruno Mondadori.

CAILLÉ, A. (2000). L'antropologie du don. Paris: Desclée de Bouwer. . (ed.) (1994), Pour une autre économie. Paris: La Decouverte.

CALLON, M. ; LATOUR, B. (1997). Tu ne calculeras pas oú comment symetriser le Don et le Capital. Revue du MAUSS, vol. 1. Paris: La Découverte.

CHAVANCE, B. (2006). L'économie institutionnelle. Paris: La Découverte.

CORIAT, B. ; SABOIA, J. (1989). Regime de Acumulação e Relação Salarial no Brasil. Ensaios FEE, v. 10, n. 1, p. 3-45.

DUHAU, E. (2001). Impactos de los programas de regularización. Notas a partir de la experiencia mexicana. Cambrigde-MA: Lincoln Institute of Land Policy. Trabalho apresentado no Workshop "Mercados informales: regularización de la tenencia de la tierra y programa de mejoramiento urbano".

DUTY, C.; WEBER, F. (2007). L'ethnographie économique. Paris: La Découverte.

GILLY, J-P.; TORRE, A. (eds) (2000). Dynamiques de proximité. Paris: Harmattan.

GOUDBOUT, J. (1992). L'esprit du don. Paris: La Decouverte.

GODELIER, M. (2007). Au foundament des société humaines. Paris: Albin Michel.

GOUDBOUT, J. (2007). Les choses qui circulent. Paris: La Découverte.

FERNANDES, E. (2003). In: Abramo (ed.), 2003.

FUJITA, M. (1989). Urban economic theory. Cambridge: University Press.

FUJITA, M.; KRUGMAN, P.; VENABLES, A. (1999). The spatial economy. Cambridge, MA: MIT Press.

JARAMILLO, S. (2007). Resenha do libro Cidade Caleidoscópica de Pedro Abramo. Ed Bertrand, 2007, revista Territórios, ACIUR, Bogotá, Colômbia.

. (2001) Recuperación de plusvalías en América Latina: Alternativas para el desarrollo urbano. Land Lines: Lincoln Institute of Land Policy, vol. 13, n. 4. MA.

KLEIN, J.; HARRISON (eds.) (2006) Linnovation sociale. Sainte-Foy, Québec: Presses de l'Université du Québec.

LIPIETZ, A. (1991). Audácia: uma alternativa para o século XXI. São Paulo: Nobel.

MACHADO, L. (ed) (1981). Solo urbano: tópicos sobre o uso da terra. Rio de Janeiro: Zahar.

MALDONADO, M. M. (2003). La plus-valia en beneficio de los pobres: el Proyecto Usme en Bogotá, Colombia, Land Lines, vol. 15, n. 2, Cambrigde-MA: Lincoln Institute of Land Policy.

MARICATO, E. (2001). Brasil, cidades: alternativas para a crise urbana. Petrópolis: Vozes.

MARQUES, E. (1998) Infra-estrutura urbana e produção do espaço metropolitano no Rio de Janeiro, Cadernos IPPUR, ano XII, volume 2, 57-7.

MAURIN, E. (2004). Le guetto français: enquête sur le separatisme social. Paris: Seuil. MOULAERT, F.; SWYNGEDOUW, E.; RODRIGUEZ, A. (2004). The Globalized City

- Economic Restructing and Social Polarization in European Cities. Oxford: OUP.

MOULAERT, F. et al (2000) Globalization and Integrated Area Development. Oxford: OUP. 
NORTH, D. (2005). Understanding the process of economic change. Princeton: Princeton Univ. Press.

PELLIGIA, V. (2007). Il paradossi della fiducia. Scelte razionali e dinamiche interpersonali Bologna: Il Mulino.

PERLMAN, J.; VAINER, C.; ABRAMO, P. (1999) A dinâmica da pobreza urbana e sua relação com as políticas públicas: trajetórias de vida em três comunidades do Rio de Janeiro 1969-2000. Washington: World Bank.

POLANYI, K. (1957). The economy as instituted process. In: Arensberg, H; Pearson, H.; Polanyi (eds).

PRETECEILLE, E.; VALLADARES, L. (2000). Favela, favelas: unidade ou diversidade da favela carioca. In: Ribeiro, L. (ed). O futuro das metrópoles. Rio de Janeiro: Ed. Revan. RALLET, A. (2000) De la globalization à la proximité geographique. In: Gilly and Torre (eds).

RALLET, A.; TORRE, A. (eds). (2007). Quelle proximité pour innover? Paris:L'Harmattan.

ROLNIK, R. (1999). Exclusão Territorial e Violência. Revista São Paulo em Perspectiva, São Paulo, v. 13, n. 4.

SABATINI, F. (2003) La segregación social del espacio en las ciudades de América Latina. Santiago de Chile: serie azul 35. Pontificia Universidad Católica de Chile.

. (2005) Relación entre promoción inmobiliaria y segregación residencial: giros insospechados de la Ciudad. Cambridge-MA: Lincoln Institute of Land Policy.

SMOLKA, M. (2003). Informalidad, pobreza y precios de la tierra. In: Smolka e Mullahy (eds.) (2007). Perspectivas urbanas: temas criticos en politicas de suelo en América Latina, Cambridge-MA: Lincoln Institute of Land Policy.

SUGAI, M. I. (2007) Relatorio Infomercado-Florianópolis. In: Abramo (2007) INFOMERCADO- Relatório Final. Rio de Janeiro: Finep/Habitare.

TARRIUS, A. (2002). La mondialization par le bas: les nouveaux nomads de l'économie souterraine. Paris: Balland.

TAYLOR, C. (2003). El multiculturalismo y la politica del reconocimiento. Madrid: Fondo de Cultura Económica de Espana.

VETTER, D.; MASSENA, R. (1981). Quem se apropria dos benefícios líquidos dos investimentos do Estado em infra-estrutura?. In: Machado (Ed.).

WILLIAMSON, O. (1985). The Economic Institutions of Capitalism. N. York: The Free Press.

ZALUAR; ALVITO (Orgs.) (1998). Um século de favela. Rio de Janeiro: FGV.

ZENOU, Y. (1996). Marché du travail et économie urbaine: un essai d'intégration. $R e-$ vue Economique, 47, p.263-88.

ZENOU, Y; SMITH, T.E. (1995). Efficiency wages, involuntary unemployment and urban spatial structure. Regional Science and Urban Economics, 25, p.547-73.

A B S T R A C T With the crisis of regulatory urban Fordism, the real estate market has reemerged as a determining force in the social coordination process of land use and in the production of intra-urban structure. The steel hand of the market retorned. This paper presents an analysis of the relation between the production of urban structure and the functioning modes of formal and informal land markets in Latin America. It proposes the hypothesis that, compared to the two traditional models: (compact mediteranean cities and the anglo saxon 

A

diffused cities), Latin American cities exhibit a particular urban structure. In these cities, the functioning of land markets produces simultaneously a compact and a diffused urban structure. This urban structure, characteristic of large Latin American cities, we designate as the "Com-Fused" City.

K E Y W O R D S Informal and formal city; urban structure; informal and formal urban Real Estate; segregation; residential mobility. 